\title{
INVESTIGATION OF A POLYELECTROLYTE DEGRADATION WITH VISCOMETRY
}

\author{
RAZISKAVA DEGRADACIJE POLIELEKTROLITA Z \\ VISKOZIMETRIJO
}

\author{
Ali Akyüz \\ Mehmet Akif Ersoy University, Bucak Emin Gulmez Technical Sciences Vocational Higher School, 310 Street, 15300 Burdur, Turkey \\ aakyuz@mehmetakif.edu.tr \\ Prejem rokopisa - received: 2018-05-13; sprejem za objavo - accepted for publication: 2018-06-28
}

doi:10.17222/mit.2018.106

\begin{abstract}
Ultrasonic degradation of a cationic polyelectrolyte, polydiallyl dimethylammonium chloride in aqueous solutions was investigated at $25^{\circ} \mathrm{C}$ for the first time according to the literature. Degradations were performed at a varying molar concentration of $\mathrm{NaCl}(0.05-0.50-1.00 \mathrm{M})$, using different sodium salts with constant molar concentrations $\left(\mathrm{Na}_{2} \mathrm{SO}_{4}, \mathrm{NaNO}_{3}, \mathrm{NaBr}\right)$ in the solution and at medium $\mathrm{pH}$ values of 1,3 and 5 . The ultrasound frequency $(20 \mathrm{kHz})$, intensity and polymer concentration were kept constant $(0.005 \mathrm{~g} / \mathrm{mL})$. By doing so, only the effect of the solvent quality was studied. The degradation process was characterized with viscometry and the Ovenall/Harrington/Madras model was successfully applied to predict the degradation parameters. The results show that the degradation efficiency depends strongly on the solvent quality.

Keywords: polyelectrolyte, polydiallyl dimethylammonium chloride, sonication, degradation, viscosity
\end{abstract}

Avtorji so raziskovali ultrazvočno degradacijo kationskega polielektrolita, to je polidialnega dimetilamonijevega klorida v vodni raztopini pri $25^{\circ} \mathrm{C}$. Poudarjajo, da gre glede na doslej objavljeno literaturo za prvo tovrstno raziskavo. Degradacije so izvajali v različnih molarnih koncentracijah $\mathrm{NaCl}(0,05-0,50-1.00 \mathrm{M})$, različnih $\mathrm{Na}$ soli s konstantno molarno koncentracijo $\left(\mathrm{Na}_{2} \mathrm{SO}_{4}\right.$, $\left.\mathrm{NaNO}_{3}, \mathrm{NaBr}\right) \mathrm{v}$ raztopini in pri srednji kislosti $\mathrm{pH} 1,3$ in 5 . Ultrazvočno frekvenco $(20 \mathrm{kHz})$, intenziteto in koncentracijo polimera $(0,005 \mathrm{~g} / \mathrm{mL})$ so ohranjali konstantne. Tako so lahko raziskovali samo kvaliteto topila. Proces degradacije so okarakterizirali z viskozimetrijo. Uspešno so uporabili Ovenall/Harrington/Madras-ov model za napoved degradacijskih parametrov. Rezultati so pokazali, da je učinkovitost degradacije močno odvisna od kvalitete topila.

Ključne besede: polielektrolit, polidialni dimetilamonijev klorid, sonikacija (ultrazvočenje), degradacija, viskoznost

\section{INTRODUCTION}

Polyelectrolytes (PEs) are polymers having many covalently bonded ionizable groups. These groups dissociate in polar solvents into macro-ions and small counterions. Electrostatic forces between macro-ions and small ions determine the characteristics of a PE in the solution. In recent years, water-soluble PE studies have increased considerably because of their diverse applications such as water purification, film coating, paper processing and biomedicine. Besides many studies about PEs, it is widely accepted that physicochemical properties of PEs are not fully understood and the subject still presents challenges. ${ }^{1-5}$ The conformation of macromolecules identified by the persistence length is formed by the combination of the bare persistence length and the electrostatic contribution. The electrostatic contribution is proportional to the square of the Debye length, which is simply the length over which the electrostatic forces are screened. Barrat, Joanny and Dobrynin stated that the electrostatic persistence length of charged flexible chains scales on the order of the Debye screening length. ${ }^{6-10}$ Polydiallyl dimethylammonium chloride (PDADMAC) is a cationic polymer, which has a backbone of cyclic units including a cationic quaternary ammonium structure within every chain that gives the polymer a better solubility comparable to that of strong PEs. PDADMAC polymers have been preferred for numerous industrial applications. They are recommended in wastewater treatment as coagulants and flocculants used for the removal of contaminants. PDADMAC homopolymers are also commonly utilized for strengthening and fixing the agents in the paper and textile industries. They are also widely used in cosmetic, medicine and food products. For that reason, PDADMAC has attracted a lot of interest recently and significant researches have focused on the understanding of physicochemical or solution characteristics and the polymerization mechanism. ${ }^{11-16}$

When high-intensity ultrasound (US) passes through a liquid and a sufficiently strong negative pressure is applied during the expansion phase, the critical distance between the liquid molecules is exceeded and cavitation bubbles form in the liquid and collapse severely at one point. The collapse of cavitation bubbles results in very short periods of enormous local temperature and pressure. In addition, cavitation results in sonophysical effects such as shear forces, velocity gradients, microstreaming, micro-jets and shock waves. ${ }^{17-19}$ The first effect of applying US to polymer solutions (sonication) is polymer degradation (polymer-chain scission). Solvodynamic forces resulting from the cavitation cause the 
polymer chain to become divided and the molecular weight to decrease. Polymer chains in a solution tend to become extended conformations under the forces performing chain cleavages to lower the chain lengths. The degradation proceeds more rapidly for longer chains and after long sonication times, the chain length reaches the limiting value. The degradation is influenced by different experimental factors including intensity, frequency, temperature, polymer concentration, dissolved gas, and initial molecular weight of the polymer. Solution characteristics have an important role in the chain scission because the effect of solvodynamic forces on polymer chains depends on the conformations of the molecules in the solution. ${ }^{18-25}$

An analysis of the literature shows that there has been no research on the ultrasonic degradation of PDADMAC and only limited research has been carried out for ultrasonic polyelectrolyte degradation. In this study, the salt and $\mathrm{pH}$ effect of the ultrasonic PDADMAC degradation in a solution were investigated using viscosity measurements. Viscosity measurement is one of the suitable and widely used techniques for describing the behavior of polymer chains in solutions. As the salt concentration or $\mathrm{pH}$ of the medium were changed, the conformation of PDADMAC chains in the solution changed and therefore the degradation effect of US also changed. A number of researchers presented various theoretical models for ultrasonic polymer degradation to explain the kinetics of this process. The polymer molecular weight or viscosity decreases rapidly at the beginning of the degradation and then approaches a fixed value. For the kinetic analysis of the PDADMAC degradation, the Ovenall/Harrington/Madras (OHM) model, which provided good results in determining the change in the molecular weight and viscosity, was used. ${ }^{20,22}$ In the present study, the PDADMAC degradation is basically monitored in terms of intrinsic viscosity.

\section{EXPERIMENTAL PART}

Commercial PDADMAC (Aldrich Mw $400,000-500,000-20 w / \%$ in $\mathrm{H}_{2} \mathrm{O}$ ) was used in this study. $\mathrm{NaCl}, \mathrm{NaBr}, \mathrm{Na}_{2} \mathrm{SO}_{4}, \mathrm{NaNO}_{3}, \mathrm{HCl}$ were obtained from Merck and distilled water was used for the solutions. Sonication was performed in a 50-mL glass flat-bottom vessel using the Bandelin GM 3100 (Bandelin Electronic, Berlin-Germany) ultrasonic homogenizer $(20 \mathrm{kHz}$ fixed frequency) with a MS73 micro-tip probe (3-mm diameter, 175-mm length). The initial PDADMAC concentration was kept constant at $0.001 \mathrm{~g} / \mathrm{mL}$, which was lower than the overlap concentration for all the sonication experiments. ${ }^{12}$ The vessel was kept in an ice-water bath at $25 \pm 1{ }^{\circ} \mathrm{C}$ during all the experiments. The sonication of the PDADMAC solutions was performed from $250 \mathrm{~s}$ to $8000 \mathrm{~s}$ to prevent a volume change as an alternative to the withdrawal of the samples from the reaction medium. It was considered that the volume change would have an effect on the sonication medium and on the results. To provide for a precise comparison, the setting was maintained during all the experiments. The experiments were repeated twice and the experimental errors were around $2 \%$. The viscosity measurements of the PDADMAC samples were carried out at room temperature with a differential viscometer. The viscometer system was formed by connecting a stainless steel tube (0.1/0.00025 m length/radius) from two ends to a differential pressure transducer (Validyne Engineering DP15-28, USA) using a $\mathrm{T}$ junction and a Validyne CD 15 indicator.

The voltage of the pressure transducer is correlative to the pressure change through the tube. The pressure change is proportional to the PDADMAC solution viscosity $\left(\eta_{\text {solution }}\right)$ according to Poisseuille's formula. The specific viscosity $\left(\eta_{\mathrm{sp}}\right)$ is the increase in the viscosity caused by the polymer in the solution. Normalization of the specific viscosity to the polymer concentration (c) is the influence of the polymer causing the solution viscosity to increase, i.e., the viscosity $\left(\eta_{\text {red }}\right)$ to reduce. $\eta_{\mathrm{sp}}$ and $\eta_{\text {red }}$ are directly calculated from the voltage output of the transducer using Equations (1) and (2). The intrinsic viscosity $[\eta]$, is known as the size of one polymer chain in the solution. The intrinsic viscosity provides more knowledge about the characteristics of the polymer and its interaction with the solvent. Single-point procedures for determining the intrinsic viscosity as outlined by the Solomon-Ciuta formula (Equation (3)) are generally suggested as a useful method for polymer-degradation experiments..$^{21,26}$ The intrinsic viscosities are determined from Equation (3). Table 1 presents an overview of the experimental conditions. The initial intrinsic $\left([\eta]_{0}\right)$ and reduced viscosities $\left(\eta_{\text {red,0 }}\right)$ are determined using Equations (2) and (3).

$$
\begin{gathered}
\eta_{\text {sp }}=\frac{\left(\eta_{\text {solution }}-\eta_{\text {solvent }}\right)}{\eta_{\text {solvent }}} \\
\eta_{\text {red }}=\frac{\eta_{\text {sp }}}{c} \\
{[\eta]=\frac{\left[2\left(\eta_{\text {sp }}-\ln \left(\eta_{\text {sp }}+1\right)\right)\right]^{0.5}}{c}}
\end{gathered}
$$

Table 1: Conditions for the experiments

\begin{tabular}{|c|c|c|}
\hline Condition & {$[\eta]_{0}(\mathrm{~mL} / \mathrm{g})$} & $\eta_{\text {red, } 0}(\mathrm{~mL} / \mathrm{g})$ \\
\hline $0.05 \mathrm{M} \mathrm{NaCl}$ & 359 & 404 \\
$0.50 \mathrm{M} \mathrm{NaCl}$ & 146 & 151 \\
$1.00 \mathrm{M} \mathrm{NaCl}$ & 103 & 107 \\
$0.50 \mathrm{M} \mathrm{Na}_{2} \mathrm{SO}_{4}$ & 155 & 166 \\
$0.50 \mathrm{M} \mathrm{NaNO}_{3}$ & 218 & 235 \\
$0.50 \mathrm{M} \mathrm{NaBr}$ & 82 & 85 \\
$\mathrm{pH} \mathrm{1}$ & 194 & 215 \\
$\mathrm{pH} \mathrm{3}$ & 386 & 425 \\
$\mathrm{pH} 5$ & 464 & 514 \\
\hline
\end{tabular}


The adapted expression of the OHM model is given in Equation (4). ${ }^{21,22}$ For the model, $[\eta]_{\mathrm{t}}$ is the intrinsic viscosity as a function of time, $[\eta]_{\text {lim }}$ is the limiting value and $\mathrm{k}$ is the degradation constant. In order to plot $\ln \left([\eta]^{-1} \lim -[\eta]_{\mathrm{t}}^{-1}\right)$ against the sonication time, $t$ gives a linear correlation and the degree of slope yields the OHM degradation constant. Here, instead of this approach, $[\eta]_{\mathrm{t}}$ was fitted using nonlinear techniques for a meaningful analysis. In addition, in this study, an index (Equation (5)) called the degradation index (DI) was used to compare the sonication experiments.

$$
\begin{gathered}
\ln \left([\eta]_{\lim }^{-1}-[\eta]_{t}^{-1}\right)=\ln \left([\eta]_{\lim }^{-1}-[\eta]_{0}^{-1}\right)-k t \\
D I=\frac{100\left([\eta]_{0}-[\eta]_{\lim }\right)}{[\eta]_{0}}
\end{gathered}
$$

\section{RESULTS AND DISCUSSION}

\subsection{Effect of the NaCl concentration}

To investigate the effect of the $\mathrm{NaCl}$ concentration on the ultrasonic PDADMAC degradation, samples with a 0.05-0.50-1.00 M NaCl concentration before the sonication were prepared. Figure 1 shows the variation of the experimental intrinsic viscosity data (represented by points) versus the sonication time and in line with the OHM model. In this figure, solid lines represent the OHM curve-fitting function. It is noted that for each experiment, the intrinsic viscosity leveled off quickly within the first $1000 \mathrm{~s}$, but a quick decrease in the sonication slowed it down during 5000-8000 s towards the limiting value. It is also observed that the beginning of the decrease in the viscosity is the most effective for the lowest amount of $\mathrm{NaCl}$ and the slowest for the highest $\mathrm{NaCl}$ concentration. Quantitatively, DI dropped from $82.89 \%$ to $67.28 \%$ and $k$ from 0.001830 to

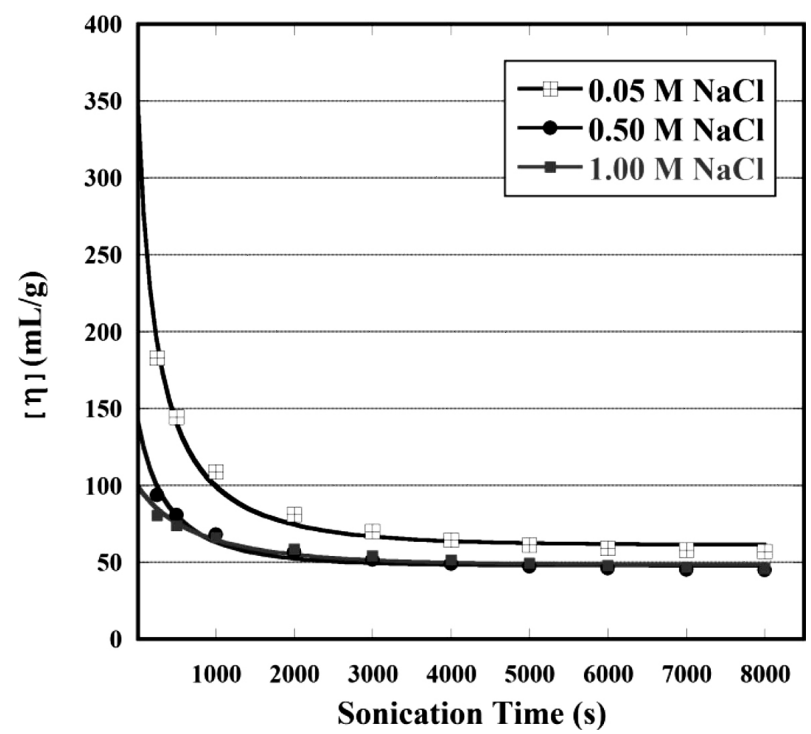

Figure 1: Effect of $\mathrm{NaCl}$ concentration on the PDADMAC degradation and the prediction of the OHM model
$0.000945 \mathrm{~s}^{-1}$ for an increase in the concentration of $\mathrm{NaCl}$ from $0.050 \mathrm{M}$ to $1.00 \mathrm{M}$. The $\mathrm{OHM}$ degradation constants, $[\eta]_{\lim }$ and degradation index are given in Table 2. The existence of $\mathrm{NaCl}$ in the PDADMAC solution prevents the Coulombic forces of ions on the chains, additionally increasing intrapolymer associations. With the increase of the $\mathrm{Cl}^{-}$ions in the solution, the electrostatic screening group of $\mathrm{N}\left(\mathrm{CH}_{3}\right)_{2}$ increases and PDADMAC chains become a more coiled formation (from $0.05 \mathrm{M}$ to $1.00 \mathrm{M} \mathrm{NaCl}$ ). It is generally accepted that the effect of degradation is greater in good solvents where the polymer chains form an expanded conformation. The degradation impact of solvodynamic forces like the shear strain are more effective for expanded PDADMAC chains $(0.05 \mathrm{M} \mathrm{NaCl})$ than coiled chain conformations $(0.50-1.00 \mathrm{M} \mathrm{NaCl})$. The result is consistent with the studies on the effect of salt concentration on polyelectrolyte such as xanthan, polystyrene sulfonate degradation. $^{21,27}$

\subsection{Effect of different sodium salts}

The influence of particular sodium salts such as $\mathrm{NaCl}, \mathrm{Na}_{2} \mathrm{SO}_{4}, \mathrm{NaNO}_{3}$ and $\mathrm{NaBr}$ on the degradation of PDADMAC was investigated for a fixed 0.50-M salt concentration. Figure 2 shows the effect of sodium salts on the degradation details of the PDADMAC solution for an 8000-s sonication. In this set of experiments, the intrinsic viscosity underwent a quick initial reduction, approaching the limiting value. Figure 2 also shows the intrinsic viscosity data (points) fitted to the OHM model (solid lines in the figure). The model presents a proper explanation of the evaluation of the intrinsic viscosity. When the $\mathrm{Na}_{2} \mathrm{SO}_{4}-\mathrm{PDADMAC}$ solution was sonicated, the intrinsic viscosity decreased efficiently from 155 to $46 \mathrm{~mL} / \mathrm{g}$ in $8000 \mathrm{~s}$. DI was $75.24 \%$ and $k$ was $0.000994 \mathrm{~s}^{-1}$. When the $\mathrm{NaNO}_{3}-\mathrm{PDADMAC}$ solution was irradiated

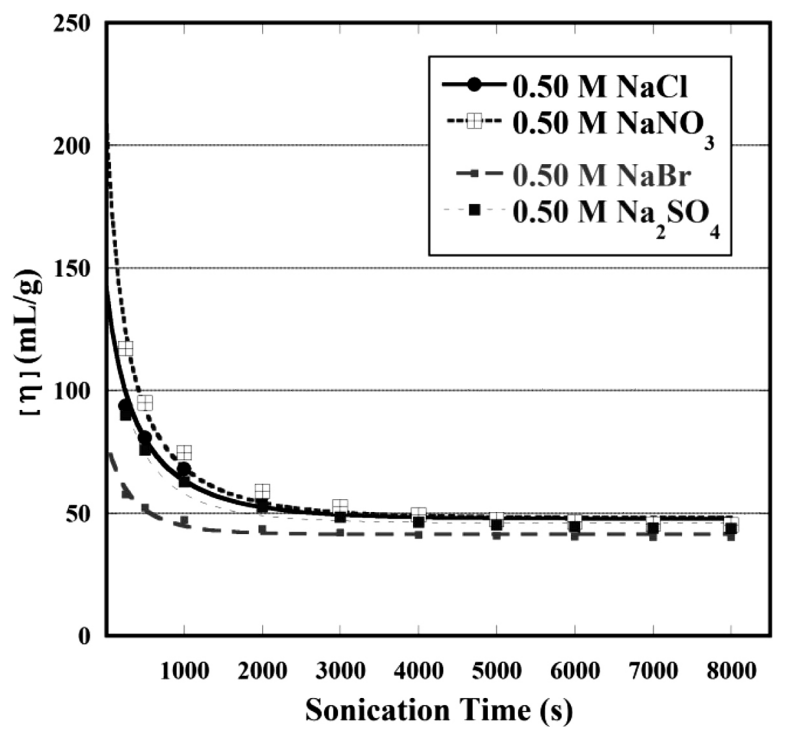

Figure 2: Effects of different salts on the PDADMAC degradation and the prediction of the OHM model 
by the ultrasound, the intrinsic viscosity decreased from $218 \mathrm{~mL} / \mathrm{g}$ to $48 \mathrm{~mL} / \mathrm{g}, D I$ was $78.23 \%$ and $\mathrm{k}$ was $0.001220 \mathrm{~s}^{-1}$. In the case of the NaBr-PDADMAC sonication, the initial and limiting intrinsic viscosities were $82 \mathrm{~mL} / \mathrm{g}$ and $41 \mathrm{~mL} / \mathrm{g}$, respectively. $D I$ was $55 \%$ and $\mathrm{k}$ was $0.000715 \mathrm{~s}^{-1}$. The results of the $0.50 \mathrm{M} \mathrm{NaCl-PDA-}$ DMAC experiment are given above. A summary of the results obtained for this set of experiments is given in Table 2. Particularly, for the $0.50-\mathrm{M}$ salt concentration, it can be noticed that the initial intrinsic viscosity increases the most with the presence of $\mathrm{NaNO}_{3}$, followed by $\mathrm{NaCl}$, $\mathrm{Na}_{2} \mathrm{SO}_{4}$ and $\mathrm{NaBr}$.

The change in the initial viscosity can be enforced by interaction variations between the PADMAC chains and the counterions. For the $\mathrm{NaCl}$ and $\mathrm{NaNO}_{3}$ solution (monovalent counterions), the intrinsic viscosity increases with the increasing counterion size as bigger ions are weakly associated with PDADMAC chains. ${ }^{13}$ In the case of the $\mathrm{Na}_{2} \mathrm{SO}_{4}$ solution (bivalent counterions), PDADMAC chains have a higher charge affinity than $\mathrm{NaCl}$ and $\mathrm{NaNO}_{3}$; therefore, polymer chains had a coiled conformation. Using $\mathrm{NaBr}$ in the PDADMAC solution reduces the solvent quality as it causes a lower intrinsic viscosity and the PDADMAC chains exhibit a more coiled conformation than in the cases of $\mathrm{NaCl}, \mathrm{Na}_{2} \mathrm{SO}_{4}$ and $\mathrm{NaNO}_{3}$. The increasing interactions between the polymer chain and counterions shows that the counterion binding is not supported by remarkable dehydration and the counterion binding is not specific for halides. ${ }^{28} \mathrm{Li}$ and Feke investigated the effect of $\mathrm{NaCl}$ and $\mathrm{Na}_{2} \mathrm{SO}_{4}$ on the nonionic locust-bean-gum degradation due to ultrasound. They showed that when $\mathrm{NaCl}$ was used, the degradation was more effective compared to the $\mathrm{Na}_{2} \mathrm{SO}_{4}$ usage. ${ }^{29}$ In another study of $\mathrm{Li}$ and Feke, it was concluded that an addition of $\mathrm{NaCl}$ to the solution was more effective than $\mathrm{Na}_{2} \mathrm{SO}_{4}$ during the ultrasonic xanthan degradation. They

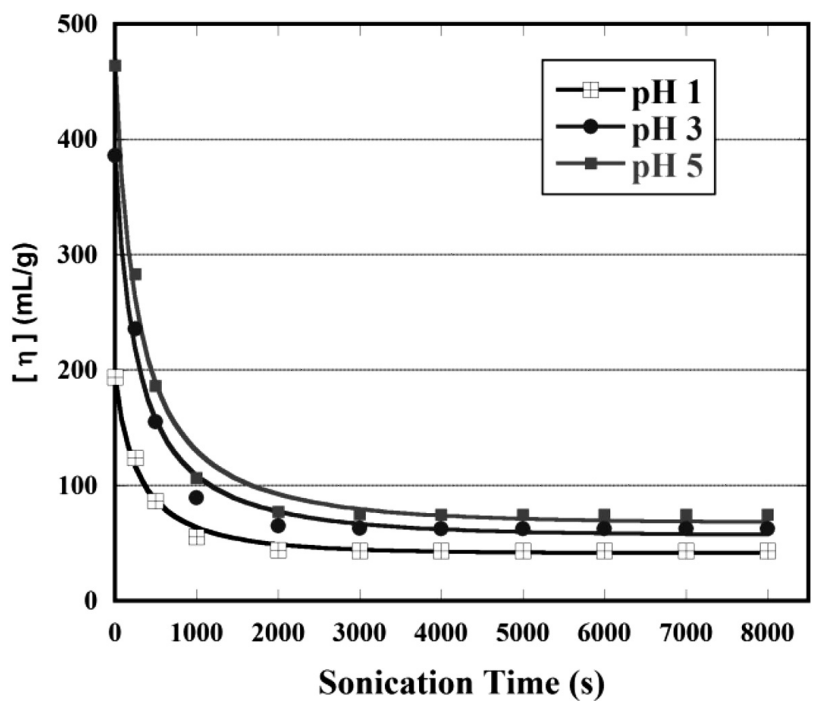

Figure 3: Effect of $\mathrm{pH}$ on the PDADMAC degradation and the prediction of the OHM model reported that xanthan exhibited a more compacted form in the $\mathrm{Na}_{2} \mathrm{SO}_{4}$ solution. ${ }^{30}$ Their results are consistent within this study.

\subsection{Effect of $p H$}

Sonications were carried out at medium $\mathrm{pH}$ values of 1, 3 and 5. pKa's of the monomer, low and high molecular weight of PDADMAC were 7.0, 6.7, and 6.3, respectively; they were positively charged in an acidic media. ${ }^{16}$ The $\mathrm{pH}$ was adjusted with $\mathrm{HCl}$. The $\mathrm{pH}$ of the solution was determined for the duration of sonication and it did not change during sonication. The evolutions of the intrinsic viscosities for this set are shown in Figure 3. This figure also shows the prediction of the OHM model (solid lines). The intrinsic viscosity for the $\mathrm{pH}$ of 1 decreased rapidly during the initial $1000 \mathrm{~s}$ from $194 \mathrm{~mL} / \mathrm{g}$ to $44 \mathrm{~mL} / \mathrm{g}$, slightly inclining toward the limiting viscosity of 43 after $7000 \mathrm{~s}$. In this experiment, $k$ and DI were determined as $0.001395 \mathrm{~s}^{-1}$ and $77.70 \%$, respectively. For the $\mathrm{pH}$ of 3 , the intrinsic viscosity decreased from $386 \mathrm{~mL} / \mathrm{g}$ to $90 \mathrm{~mL} / \mathrm{g}$ during $1000 \mathrm{~s}$ and finally the viscosity approached the value of $67 \mathrm{~mL} / \mathrm{g}$. The values of $k$ and $D I$ were calculated as $0.001950 \mathrm{~s}^{-1}$ and $83.75 \%$, respectively. The initial intrinsic viscosity reduced from $464 \mathrm{~mL} / \mathrm{g}$ to $107 \mathrm{~mL} / \mathrm{g}$ during $1000 \mathrm{~s}$ and reached $74 \mathrm{~mL} / \mathrm{g}$ at the end of $8000 \mathrm{~s}$ for the $\mathrm{pH}$ of 5 . The values of $k$ and $D I$ were calculated as $0.002150 \mathrm{~s}^{-1}$ and $83.90 \%$, respectively. A higher degradation efficiency was obtained at the $\mathrm{pH}$ of 5 and the lowest degradation efficiency was observed at the $\mathrm{pH}$ of 1 (Table 2).

The $\mathrm{pH}$ of the medium changed the solution characteristics of PDADMAC because the dissociation of the ionic groups of the polymer chains was also affected by the $\mathrm{pH}$ of the medium. At the $\mathrm{pH}$ of 1 , the number of $\mathrm{Cl}$ ions was higher than at the $\mathrm{pH}$ values of 3 and 5 . Therefore, at the $\mathrm{pH}$ of 1 , the Coulomb repulsion forces were higher due to the electrostatic screening of the $\mathrm{Cl}$ ions and the PDADMAC chains had a more compact

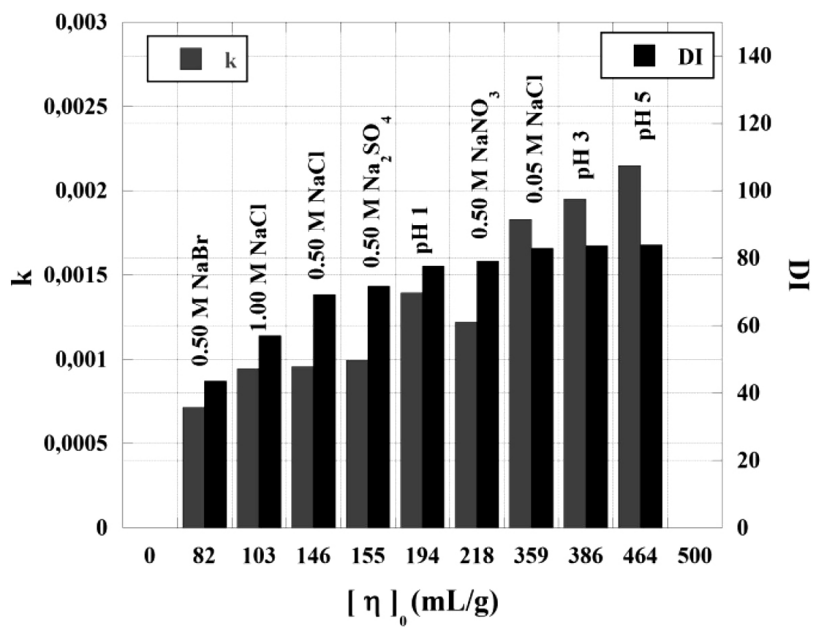

Figure 4: Variation in the OHM degradation constants and DI with the initial intrinsic viscosity 
form than at the $\mathrm{pH}$ values of 3 and 5 , at which the PDADMAC chains exhibited an expanded conformation. It is easier to break polymer chains in an expanded form. Vijayalakshmi and Madras investigated the $\mathrm{pH}$ effect on the polyvinyl-alcohol degradation. They concluded that a degradation at $\mathrm{pH}$ values of 2 and 12 was more effective than at a $\mathrm{pH}$ of 7 . It was also concluded that the polyvinyl-alcohol degradation was more efficient in the expanded form of polymer chains. ${ }^{19}$ Mehrdad studied the effect of the $\mathrm{HCl}$ concentration on the polyethylene oxide sonication and reported that the degradation efficiency was reduced at a higher $\mathrm{HCl}$ concentration. ${ }^{31} \mathrm{It}$ should be noted that polyvinyl alcohol and polyethylene oxide are not polyelectrolytes. The correlation coefficients $\left(R^{2}\right)$ from the OHM model for all the experiments are given in Table 2 .

Table 2: Degradation parameters

\begin{tabular}{|c|c|c|c|c|}
\hline Condition & $\begin{array}{c}k\left(\mathrm{~s}^{-1}\right) \times \\
10^{-4}\end{array}$ & $\begin{array}{c}{[\eta]_{\lim }} \\
(\mathrm{mL} / \mathrm{g})\end{array}$ & $R^{2}$ & $D I$ \\
\hline $0.05 \mathrm{M} \mathrm{NaCl}$ & 18.30 & 61.40 & 0.996 & 82.89 \\
$0.50 \mathrm{M} \mathrm{NaCl}$ & 9.58 & 47.76 & 0.989 & 69.26 \\
$1.00 \mathrm{M} \mathrm{NaCl}$ & 9.45 & 48.44 & 0.979 & 57.06 \\
$0.50 \mathrm{M} \mathrm{Na}_{2} \mathrm{SO}_{4}$ & 9.94 & 46.12 & 0.992 & 71.72 \\
$0.50 \mathrm{M} \mathrm{NaNO}_{3}$ & 12.20 & 48.12 & 0.994 & 79.22 \\
$0.50 \mathrm{M} \mathrm{NaBr}$ & 7.15 & 41.00 & 0.987 & 43.52 \\
pH 1 & 13.95 & 43.26 & 0.989 & 77.70 \\
pH 3 & 19.50 & 65.70 & 0.994 & 83.75 \\
pH 5 & 21.50 & 74.70 & 0.995 & 83.90 \\
\hline
\end{tabular}

The obtained results with regard to the initial intrinsic viscosity, which was a measure of the solvent quality, are given in Figure 4. The right side of the figure shows $k$ and the left side shows $D I$. The values of $k$ and $D I$ monotonically increase when the initial viscosity, i.e., the solvent quality is increased.

\section{CONCLUSIONS}

Ultrasonic techniques are useful for producing welldesigned polymers with different characteristics, scaling down the heterogeneity index of polymers, generating chemical structures for different reactions and modifying polymers for desired properties. To figure out and learn how to control these types of processes, the mechanism of the influence of US and parameters need to be investigated. That is why ultrasonic degradation continues to be studied intensively. In this study, ultrasonic polydiallyl dimethylammonium chloride degradation in aqueous solutions was studied for the first time according to the literature. The ultrasonic degradation of PDADMAC in sodium salts and $\mathrm{HCl}$ solutions was methodically investigated. It was shown that the sonication efficiently leads to a scission of PDADMAC chains. The most effective degradation occurred within the first 1000 $\mathrm{s}$ of the sonication for all the experiments. The solvent quality was controlled with the salt content in the solution and $\mathrm{pH}$ was the predominant influence during the ultrasonic PDADMAC degradation. The effect of solvodynamic forces on PDADMAC chains is higher in a better solvent, in which the chains exhibit expanded conformations. The experimental results agree with the studies by Vijayalakshmi and the previous study about the polystyrene-sulfonate degradation, indicating that the polymer-chain conformation in a solution is an important factor for the degradation. This study is also consistent with Schaefer's results, according to which the contour length is the main parameter for the ultrasonic polymer degradation. ${ }^{18,19,21,24}$

\section{Acknowledgements}

This study was partly supported by the TUBITAK project, number $115 Z 421$.

\section{REFERENCES}

${ }^{1}$ B. Bolto, J. Gregory, Organic polyelectrolytes in water treatment, Water Res., 41 (2007), 2301-2324, doi:10.1016/j.watres.2007.03.012

${ }^{2}$ L. Ghimici, Viscosity of some cationic polyelectrolyte and its potential use as flocculant in solid/liquid separation processes, J. Macromol. Sci. Part B., 48 (2009) 6, 1252-1262, doi:10.1080/ 00222340903274969

${ }^{3}$ T. Ono, M. Ohta, K. Sada, Ionic polymers act as polyelectrolytes in nonpolar media, ACS Macro Lett., 1 (2012) 11, 1270-1273, doi:10.1021/mz3002879

${ }^{4}$ J. D. Willott, T. J. Murdoch, G. B.Webber et al, Physicochemical behaviour of cationic polyelectrolyte brushes, Prog. Polym. Sci., 64 (2017), 52-75, doi:10.1016/j.progpolymsci.2016.09.010

${ }^{5}$ P. R. Suresha, M. V. Badiger, B. A. Wolf, Polyelectrolytes in dilute solution: viscometric access to coil dimensions and salt effects, RSC Adv., 5 (2015), 27674-27681, doi:10.1039/C5RA01376C

${ }^{6}$ R. Everaers, A. Milchev, V. Yamakov, The electrostatic persistence length of polymers beyond the OSF limit, Eur. Phys. J. E, 8 (2002) 1 , 3-14, doi:10.1140/epje/i2002-10007-3

${ }^{7}$ A. V. Dobrynin, Electrostatic persistence length of semiflexible and flexible polyelectrolytes, Macromolecules, 38 (2005) 22, 9304-9314, doi:10.1021/ma051353r

${ }^{8}$ W. C. Soysa, B. Dünweg, J. R. Prakash, Size, shape, and diffusivity of a single Debye-Hückel polyelectrolyte chain in solution, J. Chem. Phys., 143 (2015) 64906, 1-16, doi:10.1063/1.4928458

${ }^{9}$ M. Ingr, E. Kutálková, J. Hrnčiřík, Hyaluronan random coils in electrolyte solutions - a molecular dynamics study, Carbohydr. Polym., 170 (2017), 289-295, doi:10.1016/j.carbpol.2017.04.054

${ }^{10}$ M. Rubinstein, G. A. Papoian, Polyelectrolytes in biology and soft matter, Soft Matter, 8 (2012), 9265-9267, doi:10.1039/c2sm90104h

${ }^{11}$ E. Gunister, A. M. Bozkurt, H. Catalgil-Giz, Poly(diallyldimethylammoniumchloride)/sodium-montmorillonite composite; structure, and adsorption properties, J. Appl. Polym. Sci., 129 (2013) 3, 1232-1237, doi:10.1002/app.38792

${ }^{12}$ H. Dautzenberg, E. Görnitz, W. Jaeger, Synthesis and characterization of poly (diallyldimethylammonium chloride) in a broad range of molecular weight, Macromol. Chem. Phys., 199 (1998) 8, 1561-1571, doi:0.1002/(SICI)1521-3935(19980801)

${ }^{13}$ G. Marcelo, M. P. Tarazona, E. Saiz, Conformational properties of poly (diallyldimethyl ammonium chloride)(PDDA) determined by combination of molecular dynamics, rotational isomeric states and Monte Carlo procedures, Polymer, 45 (2004), 1321-1330, doi:10.1016/j.polymer.2003.06.002

${ }^{14}$ Z. Adamczyk, K. Jamroży, P. Batys et al., Influence of ionic strength on poly(diallyldimethylammonium chloride) macromolecule confor- 


\section{A. AKYÜZ: INVESTIGATION OF A POLYELECTROLYTE DEGRADATION WITH VISCOMETRY}

mations in electrolyte solutions, J. Colloid Interface Sci., 435 (2014), 182-190, doi:10.1016/j.jcis.2014.07.037

${ }^{15}$ P. L. Tran, E. Huynh, A. N. Hamood et al., The ability of quaternary ammonium groups attached to a urethane bandage to inhibit bacterial attachment and biofilm formation in a mouse wound model, Int. Wound J., 14 (2017), 79-84, doi:10.1111/iwj.12554

${ }^{16}$ A. Akyüz, G. Buyukunsal, A. Paril, Online monitoring of diallyldimethylammonium chloride polymerization, Polym. Eng. Sci., 54 (2014), 1350-1356, doi:10.1002/pen.23683

${ }^{17}$ A. L. Prajapat, P. R. Gogate, Intensified depolymerization of aqueous polyacrylamide solution using combined processes based on hydrodynamic cavitation, ozone, ultraviolet light and hydrogen peroxide, Ultrason. Sonochem., 31 (2016), 371-382, doi:10.1016/j.ultsonch. 2016.01.021

${ }^{18}$ M. Schaefer, B. Icli, C. Weder et al., The role of mass and length in the sonochemistry of polymers, Macromolecules, 49 (2016) 5 , 1630-1636, doi:10.1021/acs.macromol.5b02362

${ }^{19}$ S. P. Vijayalakshmi, G. Madras, Effects of the $\mathrm{pH}$, concentration, and solvents on the ultrasonic degradation of poly (vinyl alcohol), J. Appl. Polym. Sci., 100 (2006), 4888-4892, doi:10.1002/app.23280

${ }^{20}$ G. Madras, S. Kumar, S. Chattopadhyay, Continuous distribution kinetics for ultrasonic degradation of polymers, Polym. Degrad. Stab., 69 (2000) 1, 73-78, doi:10.1016/S0141-3910(00)00042-2

${ }^{21}$ A. Akyüz, O. Kamer, A. Giz, Online viscometric monitoring of ultrasonic sodium poly (styrene sulfonate) scissions, J. Macromol. Sci., Part A: Pure Appl. Chem., 50 (2013) 5, 535-540, doi:10.1080/ 10601325.2013.781459

${ }^{22}$ A. Akyüz, H. Catalgil-Giz, A. T. Giz, Kinetics of ultrasonic polymer degradation: comparison of theoretical models with on-line data, Macromol. Chem. Phys., 209 (2008) 8, 801-809, doi:10.1002/macp. 200700533

${ }^{23}$ A. Akyüz, H. Catalgil-Giz, A. Giz, Effect of solvent characteristics on the ultrasonic degradation of poly (vinylpyrrolidone) studied by on-line monitoring, Macromol. Chem. Phys., 210 (2009), 1331-1338, doi:10.1002/macp.200900098

${ }^{24}$ S. P. Vijayalakshmi, G. Madras, Effect of initial molecular weight and solvents on the ultrasonic degradation of poly (ethylene oxide), Polym. Degrad. Stab., 90 (2005) 16, 116-122, doi:10.1016/j.polymdegradstab.2005.02.018

${ }^{25}$ Q. Zhou, Y. Liu, G. Yu et al., Degradation kinetics of sodium alginate via sono-Fenton, photo-Fenton and sono-photo-Fenton methods in the presence of $\mathrm{TiO}_{2}$ nanoparticles, Polym. Degrad. Stab., 135 (2017), 111-120, 10.1016/j.polymdegradstab.2016.11.012

${ }^{26}$ A. L. Prajapat, P. R. Gogate, Depolymerization of guar gum solution using different approaches based on ultrasound and microwave irradiations, Chem. Eng. Process. Process Intensif., 88 (2015), 1-9, doi:10.1016/j.cep.2014.11.018

${ }^{27}$ H. M. Saleh, M. S. M. Annuar, K. Simarani, Ultrasound degradation of xanthan polymer in aqueous solution: its scission mechanism and the effect of $\mathrm{NaCl}$ incorporation, Ultrason. Sonochem., 39 (2017), 250-261, doi:10.1016/j.ultsonch.2017.04.038

${ }^{28}$ L. Ghimici, S. Dragan, Behaviour of cationic polyelectrolytes upon binding of electrolytes: effects of polycation structure, counterions and nature of the solvent, Colloid Polym. Sci., 280 (2002), 130-134, doi:10.1007/s003960100575

${ }^{29}$ R. Li, D. L. Feke, Rheological and kinetic study of the ultrasonic degradation of locust bean gum in aqueous saline and salt-free solutions, Ultrason. Sonochem., 27 (2015), 334-338, doi:10.1016/ j.ultsonch.2015.05.043

${ }^{30}$ R. Li, D. L. Feke, Rheological and kinetic study of the ultrasonic degradation of xanthan gum in aqueous solution: effects of pyruvate group, Carbohydr. Polym., 124 (2015), 216-221, doi:10.1016/ j.carbpol.2015.02.018

${ }^{31}$ A. Mehrdad, Effect of $\mathrm{HCl}$ and solution concentration on the ultrasonic degradation of aqueous solutions of poly (ethylene oxide), Poly. Eng., 28 (2008) 9, 597-610, doi:10.1515/polyeng.2008. 28.9.597 